\title{
REDUCED HAND GRIP STRENGTH IN OVERWEIGHT AND OBESE CHRONIC HEPATITIS C PATIENTS
}

\author{
Juliana Paula BRUCH ${ }^{1,2}$, Mário Reis ÁLVARES-DA-SILVA ${ }^{1,3,4}$, Bruna Cherubini ALVES ${ }^{1,2}$ \\ and Valesca DALL' ALBA ${ }^{1,2,5,6}$
}

Received 9/7/2015

Accepted 2/12/2015

\begin{abstract}
Background - Hepatitis C is a liver disease that causes significant changes in metabolism, and also has an impact on nutritional status. Objective - To evaluate the nutritional status and cardiovascular risk in patients with chronic hepatitis C. Methods - This cross-sectional study investigated 58 patients with chronic hepatitis $\mathrm{C}$, non-cirrhotic and were not under active pharmacological treatment. Patients with significant alcohol consumption (greater than $10 \mathrm{~g}$ ethanol/day) were excluded. Patients underwent nutritional assessment through anthropometric measurements and functional assessment using hand grip strength by dynamometry. The physical activity was assessed using the International Physical Activity Questionnaire. Patients also underwent clinical and laboratory evaluation. Cardiovascular risk was calculated by the Framingham score. Results - The mean age of patients was $51.6 \pm 9.7$ years, $55.2 \%$ were female, and $79.3 \%$ had genotype 1 . The most prevalent degree of fibrosis was F1 (37.9\%) followed by F2 (27.6\%) and F3 $(1.7 \%)$. The prevalence of overweight/obesity considering the body mass index was $70.7 \%$. However, $57.7 \%$ of men and $68.8 \%$ of women were considered malnourished according to hand grip strength. These patients also had waist circumference $(93.5 \pm 10.7$ $\mathrm{cm})$ and neck circumference $(37.0 \pm 3.6 \mathrm{~cm})$ high. Almost $60 \%$ of patients were considered sedentary or irregularly active. In relation to cardiovascular risk, $50 \%$ of patients had high risk of suffering a cardiovascular event within 10 years. Conclusion - Although most patients with hepatitis $\mathrm{C}$ presented overweight, associated with high cardiovascular risk, they also have reduced functional capacity, indicative of protein-caloric commitment. Therefore, body mass index can not be considered the only method of assessment for nutritional diagnosis of patients with liver disease. Adopting methods such as hand grip strength can be important for a better understanding of nutritional status of these patients.

HEADINGS - Nutrition assessment. Chronic hepatitis C. Hand strength.
\end{abstract}

\section{INTRODUCTION}

Hepatitis C Virus (HCV) infection is characterized by high rates of fibrosis and chronic clinical course and many patients also progress to cirrhosis or even hepatocellular carcinoma. Hepatitis $\mathrm{C}$ is considered a severe public health problem with a significant social and economic impact ${ }^{(2,20,27,31,39)}$.

While much research has been conducted with cirrhotic patients, few studies have been conducted to evaluate nutritional risk in chronic hepatitis $\mathrm{C}$ patients at earlier stages of disease progression. The deterioration of nutritional status seen in patients with cirrhosis is well known ${ }^{(16,18,28,30)}$, but patients with chronic hepatitis $\mathrm{C}$ appear to exhibit more overweight and obesity. Two different studies have shown a mean of overweight in patients with chronic $\mathrm{HCV}$ infection through body mass index (BMI): from $26.4 \pm 4.8^{(8)}$ to $28.61 \pm 5.06^{(24)} \mathrm{kg} / \mathrm{m}^{2}$. Loguercio et al. in a study with $1084 \mathrm{HCV}$ infected patients, observed that $49 \%$ of men and $59 \%$ of women were overweight. Another study, in Italy, with 180 chronic $\mathrm{HCV}$ infected patients, found a prevalence of $44 \%$ of BMI greater than $25 \mathrm{~kg} / \mathrm{m}^{2(1)}$.

Obesity has become a worldwide public health problem, affecting both developed countries and those in development ${ }^{(41)}$. The high prevalence of obesity is accompanied by an increase in cardiovascular risk factors, such as dyslipidemia, chronic inflammations, insulin resistance and type 2 diabetes mellitus, beyond an increased incidence of nonalcoholic fatty liver disease (NAFLD) ${ }^{(32)}$. In terms of its relationship to liver disease, it is well known that patients with chronic $\mathrm{HCV}$ who are overweight have worse prognosis than those at adequate weight ${ }^{(1)}$.

There is not yet consensus on the ideal method for conducting nutritional assessments of patients with chronic hepatitis $\mathrm{C}$, but several different methods have been used, including dietary recalls, analyses of dietary intake, subjective global assessments, anthropometry and biochemical parameters ${ }^{(16)}$.

Declared conflict of interest of all authors: none

Financial Support: This study was supported by a grant from CAPES and FIPE/HCPA. The funding sources were not involved in study design; in the collection, analysis and interpretation of data; in the writing of the report; or in the decision to submit the paper for publication.

${ }_{1}^{1}$ Programa de pós-graduação: Ciências em Gastroenterologia e Hepatologia, Faculdade de Medicina, Universidade Federal do Rio Grande do Sul (UFRGS), Porto Alegre, RS, Brasil; ${ }^{2}$ Centro de Estudos em Alimentação e Nutrição (CESAN), Hospital de Clínicas de Porto Alegre, UFRGS, Porto Alegre, RS, Brasil; ${ }^{3}$ Departamento de Medicina Interna, Faculdade de Medicina, UFRGS, Porto Alegre, RS, Brasil; ${ }^{4}$ Divisão de Gastroenterologia, Hospital de Clínicas de Porto Alegre, UFRGS, Porto Alegre, RS, Brasil; ${ }^{5}$ Departamento de Nutrição, Faculdade de Medicina, UFRGS, Porto Alegre, RS, Brasil; ${ }^{6}$ Divisão de Nutrição, Hospital de Clínicas de Porto Alegre, UFRGS Porto Alegre, RS, Brasil

Correspondence:Juliana Paula Bruch. Rua Ramiro Barcelos, 2400, Santana - CEP: 90035-003 - Porto Alegre, RS, Brasil. E-mail: julianabruch@gmail.com 
In addition, functional assessment using measures of hand grip strength (HGS) obtained with dynamometry is being strongly recommended as a useful method for both nutritional diagnosis and nutritional monitoring, since it is a highly sensitive method that is capable of early detection of changes such as loss of strength and protein depletion ${ }^{(16,25,36)}$. Several studies have consistently and repeatedly demonstrated that HGS is the most sensitive method for detecting nutritional risk in patients with cirrhosis ${ }^{(4,16,36)}$.

Nunes et al ${ }^{(30)}$ assessed 119 cirrhotic patients with hepatitis $\mathrm{C}$, using several different methods of nutritional assessment. The dynamometry method detected the highest prevalence of malnutrition (58.8\%), followed by triceps skinfold (34.5\%), arm circumference $(31.1 \%)$, muscular circumference of arm (29.4\%), adductor pollicis muscle thickness (APMT; $14.3 \%$ ) and subjective global nutritional assessment (6.4\%), while BMI detected the lowest prevalence (5.9\%). Another similar study, also with patients with chronic $\mathrm{HCV}$, found the highest number of patients with abnormalities compatible with malnutrition using HGS $(61 \%)^{(16)}$.

In response to the scarcity of literature on the nutritional profile of patients with $\mathrm{HCV}$, this study was conducted with the objective of evaluating nutritional status and cardiovascular risk in chronic hepatitis $\mathrm{C}$ patients.

\section{METHODS}

This cross-sectional study enrolled adults patients with chronic hepatitis $\mathrm{C}$, genotypes 1,2 or 3 , attended at the Gastroenterology Division's outpatient Clinic at Hospital de Clínicas de Porto Alegre, Brazil, from October 2013 to June 2014. At the time of data collection, all patients had either been off antiviral treatment for at least 4 months or had never had such treatment. The research protocol was approved by the Research Ethics Committee at Hospital de Clínicas de Porto Alegre and all patients were only enrolled after they had read, understood and signed a free and informed consent form.

Hepatitis $\mathrm{C}$ virus infections were confirmed by anti-HCV ELISA 3 and by detection of viral RNA by polymerase chain reaction (HCV RNA PCR). Patients had undergone liver biopsy, as the clinic's routine practice, up to 12 months before enrollment on study. Only specimens with more than 10 portal spaces were considered for analysis. All samples were analyzed by the same experienced pathologist who was blind to all other details of each case. Patients were excluded if they had cirrhosis (whether diagnosed by clinical criteria or anatomopathological findings), hepatocellular carcinoma or other malignant tumors, coinfection with HIV or HBV, liver transplantation, pregnancy, active antiviral treatment or significant alcohol consumption (over $10 \mathrm{~g}$ of ethanol/day) ${ }^{(23)}$.

\section{Anthropometric assessment}

Anthropometric assessment consisted of evaluating BMI and waist circumference (WC; measured at the midpoint between the last rib and the iliac crest) as recommended by the World Health Organization (WHO) ${ }^{(40)}$; arm circumference (AC; measured at the midpoint between the acromion and olecranon on the posterior surface of the non-dominant arm, in relaxation); and triceps skinfold (TSF; 3 measurements) as used in the National Health and Nutrition Examination Survey (NHANES) ${ }^{(17)}$. Neck circumference (NC) was measured by the smallest circumference just above the laryngeal prominence with patient sitting down or standing up, with the spine erect and the head in the Frankfurt horizontal plane ${ }^{(6)}$. The APMT was measured with the subject sitting down, with the ventral surface of the hand resting on the knee and the elbow at an angle of approximately $90^{\circ}$ on the homolateral lower $\operatorname{limb} b^{(21)}$. Patients were weighed in light clothing and unshod using a Filizola balance with $150 \mathrm{~kg}$ capacity and TSF were measured with a scientific adipometer $\left(\right.$ Lange $^{\mathbb{B}}$ ) with precision of $1 \mathrm{~mm}$, while all other measurements were taken using a $150 \mathrm{~cm}$ inextensible anthropometric tape.

\section{Functional assessment}

Functional assessment consisted of measuring grip strength of the non-dominant hand, using a $\operatorname{Jamar}^{\circledR}$ mechanical dynamometer and recording the result in $\mathrm{kgf}^{(3)}$. Patients were positioned sitting down with a straight back and no armrests and with elbow flexion at $90^{\circ}$. They were first shown how to use the apparatus and allowed to practice with the dominant hand to familiarize ourselves with the device. Patients were then requested to grip the dynamometer with their non-dominant hand using maximum strength for 3 seconds. The test was repeated three times at 1-minute intervals and the maximum score recorded was used for analysis ${ }^{(36)}$.

\section{Physical activity assessment}

Physical activity levels were assessed using the short form of the International Physical Activity Questionnaire (IPAQ), on the basis of the quantity of physical activity engaged in during the previous week ${ }^{(11)}$.

\section{Cardiovascular risk assessment}

Cardiovascular risk was assessed by calculating the Framingham score ${ }^{(12)}$, which predicts a 10 -year risk of suffering a cardiovascular event on the basis of the following factors: age, total cholesterol, HDL cholesterol, systolic arterial blood pressure and presence/absence of diabetes mellitus and smoking.

\section{Statistical analysis}

Results for quantitative variables were expressed as means and standard deviations and results for qualitative variables were expressed as frequencies and percentages.

\section{RESULTS}

A total of 58 patients of both sexes with chronic hepatitis C, without cirrhosis, were enrolled from 2013 to 2014. Of these 58 patients, 39 (67.2\%) exhibited differing degrees of liver fibrosis. F1 was the most prevalent degree $(37.9 \%)$, followed by F2 $(27,6 \%)$, and F3 $(1,7 \%)^{(5)}$. The general characteristics of the study population and their cardiovascular risk are described in Table 1. 
TABLE 1. Clinical characteristics of patients with chronic hepatitis $C$

\begin{tabular}{lc}
\hline & $(\mathrm{n}=58)$ \\
Sex (female) & $32(55.2 \%)$ \\
Ethnicity (Caucasian) & $22(73.3 \%)$ \\
Genotype & \\
$\quad 1$ & $46(79.3 \%)$ \\
2 & $1(1.7 \%)$ \\
3 & $10(17.2 \%)$ \\
Age (years) & $51.6 \pm 9.7$ \\
Active smoking & $11(19.0 \%)$ \\
Systolic arterial blood pressure $(\mathrm{mmHg})$ & $136.7 \pm 19.9$ \\
Diastolic arterial blood pressure $(\mathrm{mmHg})$ & $82.5 \pm 10.4$ \\
Cardiovascular risk* & \\
$\quad$ Low (<5\%) & $17(29.3 \%)$ \\
$\quad$ Moderate $(5$ to $10 \%)$ & $12(20.7 \%)$ \\
$\quad$ High $(\geq 10 \%)$ & $29(50.0 \%)$ \\
Physical activity & \\
Inactive or irregularly active & $33(56.9 \%)$ \\
*Cardiovascular disease risk estimate, percentage in 10 years, calculated according to \\
Framingham study, 2008.
\end{tabular}

Analysis of patients by BMI ( $<25 \mathrm{vs} \geq 25 \mathrm{~kg} / \mathrm{m}^{2}$ ) showed that those with overweight/obesity had lower HGS than patients with healthy weight ( $27.8 \pm 10.8$ vs $29.6 \pm 10.0 \mathrm{kgf})$, but the difference was not statistically significant. Also, it was not found any statistical difference comparing HGS with other clinical characteristics, such as gender, age and liver fibrosis.

Patients' anthropometric characteristics are given in Table 2. The prevalence of overweight/obesity according to BMI was $70.7 \%$. For HGS, $15(57.7 \%)$ of men and $22(68.8 \%)$ of women had HGS values below the 50th percentile. Mean $\mathrm{NC}$ for men was $40.0 \pm 2.9 \mathrm{~cm}$, with $34.6 \pm 1.8 \mathrm{~cm}$ for the women; and mean APMT were $16.5 \pm 3.4 \mathrm{~mm}$ and $14.8 \pm 2.7 \mathrm{~mm}$, for men and women respectively (Table 3 ).

TABLE 2. Anthropometric and functional characteristics of patients with chronic hepatitis $\mathrm{C}$

\begin{tabular}{|c|c|}
\hline Body mass index $\left(\mathrm{kg} / \mathrm{m}^{2}\right)$ & $27.3 \pm 4.0^{2}$ \\
\hline \multicolumn{2}{|l|}{ WC - elevated ${ }^{\mathrm{b}}$} \\
\hline Men & $15(57.7 \%)$ \\
\hline Women & $26(81.3 \%)$ \\
\hline \multicolumn{2}{|l|}{ AC - above $\mathrm{p} 50^{c}$} \\
\hline Men & $11(42.3 \%)$ \\
\hline Women & $26(81.3 \%)$ \\
\hline \multicolumn{2}{|l|}{ TSF - above $\mathrm{p} 50^{\mathrm{d}}$} \\
\hline Men & $18(69.2 \%)$ \\
\hline Women & $26(81.3 \%)$ \\
\hline \multicolumn{2}{|l|}{$\mathrm{NC}$ - above mean ${ }^{\mathrm{e}}$} \\
\hline Men & $25(96.2 \%)$ \\
\hline Women & $23(71.9 \%)$ \\
\hline \multicolumn{2}{|l|}{ APMT - above mean $^{f}$} \\
\hline Men & $19(73.1 \%)$ \\
\hline Women & $30(93.8 \%)$ \\
\hline \multicolumn{2}{|l|}{ HGS below p $50^{g}$} \\
\hline Men & $22(68.8 \%)$ \\
\hline Women & $15(57.7 \%)$ \\
\hline
\end{tabular}

TABLE 3. Values for grip strength (kgf) of non-dominant hand in patients with chronic hepatitis $C$

\begin{tabular}{lccc}
\hline Age group & N & Male & Female \\
\hline $20-29$ & 2 & - & $21.0 \pm 0.0$ \\
$30-39$ & 6 & $40.0 \pm 5.7$ & $24.0 \pm 3.7$ \\
$40-49$ & 13 & $37.5 \pm 7.5$ & $21.6 \pm 5.3$ \\
$50-59$ & 26 & $37.7 \pm 8.2$ & $22.0 \pm 8.3$ \\
$60-69$ & 10 & $35.2 \pm 8.4$ & $35.2 \pm 8.4$ \\
$\geq 70$ & 1 & $28.0 \pm 0.0$ & - \\
\hline
\end{tabular}

\section{DISCUSSION}

Patients with chronic hepatitis $\mathrm{C}$ assessed in this study exhibited a high rate of overweight/obesity and had below-normal values for HGS.

Assessing nutritional status in patients with liver disease throws up many challenges, since there is no single method that can be used to precisely diagnose the nutritional status of these patients. Early detection of patients at nutritional risk and appropriate dietary prescriptions could help to minimize the consequences of hepatitis $\mathrm{C}^{(16)}$.

There are many studies in the literature that have assessed the nutritional status of cirrhotic patients, finding significant abnormalities providing evidence of malnutrition ${ }^{(8,16,18,28)}$. Few studies have been conducted of the anthropometric and nutritional profiles of patients with chronic liver disease, but it does appear to be more common for these patients to exhibit elevated $\mathrm{BMI}^{(1,8,13,24,39)}$. Metabolic and physical changes resulting from cirrhosis, including changes to the proportion of water in the body, due to ascites and edema, may be a major source of confounding factors when assessing nutritional status, particularly with overweight patients ${ }^{(26)}$. Notwithstanding, the elevated BMI observed in this study is unlikely to be related to accumulation of liquids since this sample did not contain patients with cirrhosis or with edema and/or ascites.

With relation to body weight, it is known that the increased prevalence of obesity is to a great extent due to physical inactivity and excessive food intake ${ }^{(29)}$. With regard to physical activity, the IPAQ assessment showed that almost $56.9 \%$ of patients had low weekly physical activity levels, whether in the form of domestic activities or leisure, which can lead to low energy expenditure, further contributing to excess weight. Wolf et al. ${ }^{(42)}$ demonstrated that overweight people with NAFLD who followed a controlled diet for weight reduction combined with physical activity for 15 months exhibited improvements in alanine aminotransferase and insulin levels, achieved improvements in quality of life, reductions in risk of diabetes mellitus, hypertension, dyslipidemia and steatosis, and improvements in hepatic fibrosis and inflammatory activity.

Analysis of WC showed that $72.4 \%$ of patients assessed had WC larger than recommended by the WHO, in common with results published by Pretta et al. ${ }^{(33)}$. Localized body fat in abdominal region, irrespective of patient's total fat volume, 
is an independent predictive factor of fat buildup in hepatocytes and as such is a determining factor in the pathogenesis of NAFLD ${ }^{(9)}$. Onset of NAFLD is characterized by increase in intracellular triglycerides content caused by an imbalance between synthesis and breakdown of triglycerides and when accompanied by obesity and insulin resistance this imbalance can be more extreme, in addition to triggering tissue lypolysis and resulting in build-up of lipids in hepatocytes ${ }^{(38)}$. These lipid stocks can reach toxic levels, increasing oxidative stress, with formation of free radicals and mitochondrial damage. The abnormal lipid peroxidation will lead to liver damage with inflammation and even fibrosis ${ }^{(38)}$. Obesity and, more specifically, the level of intra-abdominal fat, are positively associated with $\mathrm{RI}$ and metabolic syndrome ${ }^{(14)}$, which in turn is correlated with more rapid progression to fibrosis in patients with hepatitis $\mathrm{C}^{(43)}$.

Fat accumulation in the abdominal region is also associated with increased risk of cardiovascular disease ${ }^{(37)}$. Indeed, practically $70 \%$ of the patients assessed in this study exhibited moderate or high risk of suffering a cardiovascular event within 10 years, similar to results reported for diabetic patients and patients with metabolic syndrome ${ }^{(34)}$.

It is already described that patients with obesity have reduced handgrip strength measured by dynamometry ${ }^{(10)}$. In this study, we also found elevated prevalences of overweight/ obesity and malnutrition in chronic hepatitis $\mathrm{C}$ patients, according to dynamometry-based assessment using reference values published by Schlüssel ${ }^{(36)}$. Gottschall et al..$^{(16)}$ and Álvares-da-Silva and Silveira ${ }^{(3)}$ classified HGS results for chronic HCV patients without cirrhosis, and, also observed values below the average (61\%). Comparing our results with this parameter ${ }^{(3)}$, the prevalence of malnutrition remains elevated $(58.6 \%)$. It is worth emphasizing that the patients we evaluated were not on any type of antiviral treatment, bearing in mind that medications such as pegylated interferon and ribavirin are linked with several side effects, such as nausea, vomiting and lack of appetite, among others; which are also factors that contribute to exacerbation of poor nutritional status ${ }^{(22)}$.

Using HGS as a measurement of muscle strength may prove to be of great utility, since it is a rapid technique that is easily reproducible, low-cost and sensitive to nutritional changes. It offers the advantage of technical practicality, since it is a noninvasive procedure, making it applicable for wide scale use in population, and it is also inexpensive ${ }^{(3)}$.

It has already been shown that using BMI alone is not a safe method for nutritional assessment of cirrhotic patients ${ }^{(15,19,35)}$. Additionally, body weight appears to be less correlated with disease progression and particularly with degree of fibrosis than with dietary components ${ }^{(7)}$. On the other hand, WC may have indications as a useful parameter for assessment of patients with liver disease in order to identify risk of metabolic disorders.

\section{CONCLUSION}

It appears that weight loss occurs at more advanced stages of hepatic and nutritional ill health, when the disease has already exacerbated and other clinical parameters have also deteriorated. Adoption of methods that can be used for early identification of changes in nutritional status, such as HGS, could prove of great value for taking the decision to adopt more aggressive dietary management that is more effective for countering the initial stages of protein depletion, thereby contributing to improve prognosis. The elevated body fat percentage observed in this sample of patients with chronic hepatitis $\mathrm{C}$ may be an important risk factor for emergence of cardiovascular diseases and other associated complications, in addition to having a direct impact on these people's quality of life.

\section{ACKNOWLEDGMENTS}

To Dr. Sidia Maria Callegari Jacques for her help in the statistical analysis. To Nutritionists Flávia Moraes Silva and Juliana Peçanha Antônio for their helps with study design.

\section{Authors' contributions}

Bruch JP: protocol/project development, data collection and management, data analysis, manuscript writing/editing. Álvares-da-Silva MR: project development, and manuscript writing/editing. Alves BC: data collection, manuscript writing/editing. Dall'Alba V: protocol/project development, management, data analysis, manuscript writing/editing.

Bruch JP, Álvares-da-Silva MR, Alves BC, Dall'Alba V. Força do aperto de mão reduzida em pacientes com sobrepeso e obesidade portadores de hepatite C crônica. Arq Gastroenterol. 2016,53(1):31-5.

RESUMO - Contexto - A hepatite C é uma doença hepática que provoca alterações importantes no metabolismo e também tem impacto no estado nutricional Objetivo - Avaliar o estado nutricional e o risco cardiovascular em pacientes com hepatite C crônica. Métodos - Este estudo transversal investigou 58 pacientes com hepatite $\mathrm{C}$ crônica, não cirróticos e que não estavam sob tratamento farmacológico ativo. Pacientes com consumo de álcool significativo (maior de $10 \mathrm{~g} \mathrm{de}$ etanol/dia) foram excluídos. Os pacientes realizaram avaliação nutricional, através de medidas antropométricas, e avaliação funcional, através da medida da força do aperto de mão pela dinamometria. A prática de atividade física foi avaliada através do Questionário Internacional de Atividade Física. Os pacientes também passaram por avaliação clínica e laboratorial. O risco cardiovascular foi calculado pelo escore de Framingham. Resultados - A média de idade dos pacientes foi 51,6 $\pm 9,7$ anos, $55,2 \%$ eram do sexo feminino, e 79,3\% apresentavam genótipo 1 . O grau de fibrose mais prevalente foi F1 $(37,9 \%)$, seguido por F2 $(27,6 \%)$ e F3 $(1,7 \%)$. A prevalência de sobrepeso/obesidade considerando o índice de massa corporal foi de $70,7 \%$. No entanto, $57,7 \%$ dos homens e $68,8 \%$ das mulheres foram considerados desnutridos de acordo com a força do aperto de mão. Estes pacientes também apresentaram circunferência da cintura $(93,5 \pm 10,7 \mathrm{~cm})$ e circunferência do pescoço $(37,0 \pm 3,6 \mathrm{~cm})$ elevados. Quase $60 \%$ dos pacientes foram considerados sedentários ou irregularmente ativos. Em relação ao risco cardiovascular, $50 \%$ dos pacientes apresentou elevado risco de sofrer evento cardiovascular em 10 anos. Conclusão - Apesar de grande parte dos pacientes com hepatite $\mathrm{C}$ apresentarem excesso de peso, associado a alto risco cardiovascular, os mesmos também apresentaram diminuição da capacidade funcional, indicativa de comprometimento proteico-calórico. Portanto, o índice de massa corporal não pode ser considerado o único método de avaliação para diagnóstico nutricional de pacientes com doença hepática. Adotar métodos como a força do aperto de mão pode ser importante para uma melhor compreensão do estado nutricional destes pacientes.

DESCRITORES - Avaliação nutricional. Hepatite C crônica. Força da mão. 


\section{REFERENCES}

1. Adinolfi LE, Gambardella M, Andreana A, Tripodi MF, Utili R, Ruggiero G. Steatosis Accelerates the Progression of Liver Damage of Chronic Hepatitis C Patients and Correlates With Specific HCV Genotype and Visceral Obesity. Hepatology. 2011;33:1358-64.

2. Adinolfi LE, Restivoa L, Zampinoa R, Guerreraa B, Lonardoc A, Ruggieroa L, et al. Chronic HCV infection is a risk of atherosclerosis. Role of HCV and HCV-related steatosis. Atherosclerosis. 2012;221:496-502.

3. Álvares-da-Silva MR, Silveira TR. O estudo da força do aperto da mão nãodominante em indivíduos sadios. Determinação dos valores de referência para o uso da dinamometria. GED. 1998;17:203-6.

4. Álvares-da-Silva MR, Silveira TR. Comparison between handgrip strength, subjective global assessment, and prognostic nutritional index in assessing malnutrition and predicting clinical outcome in cirrhotic outpatients. Nutrition . 2005;21:113-7.

5. Bedossa P, Poynard T. An algorithm for the grading of activity in chronic hepatitis C. The METAVIR Cooperative Study Group. Hepatology 1996;24:289-93.

6. Ben-Noun L, Sohar E, Laor A. Neck circumference as a simple screening measure for identifying overweight and obese patients. Obes Res. 2001;9:470-7.

7. Bruch JP, Álvares-Da-Silva MR, Alves BC, Dall'Alba V. Perfil metabólico, indicadores dietéticos e antropométricos em pacientes portadores de Hepatite C crônica. Semana Panamericana de las Enfermedades Digestivas (SPED), 44, 2014 Buenos Aires-AR.

8. Careirra CM, Pereira PCM. Perfil nutricional e dietético de indivíduos com hepatite C. Semina: Ciências Biológicas e da Saúde. 2011;32:143-154.

9. Chaves GV, Souza DS, Pereira SE, SaboyaCJ, Peres WAF. Associação entre doença hepática gordurosa não alcoólica e marcadores de lesão/função hepática com componentes da síndrome metabólica em indivíduos obesos classe III. Rev. Assoc. Med. Bras. 2012;58:288-93.

10. Ching-I C, Kuo-Chin H, Ding-Cheng C, Chih-Hsing W, Cheng-Chieh L, Chao AH, Chih-Cheng $\mathrm{H}$, Ching-Yu C. The impacts of sarcopenia and obesity on physical performance in the elderly. Obesity Research \& Clinical Practice 2015;9:256-65.

11. Craig CL, Marshall AL, Sjostrom M, Bauman AE, Booth ML, Ainsworth BE. International physical activity questionnaire: 12-country reliability and validity. Med Sci Sports Exerc. 2003;35:1381-95.

12. D'Agostino RB Sr, et al. General cardiovascular risk profile for use in primary care: the Framingham Heart Study. Circulation. 2008;117:743-53.

13. Elias MC, Parise ER, de Carvalho L, Szejnfeld D, Netto JP. Effect of 6-month nutritional intervention on non-alcoholic fatty liver disease. Nutrition. 2010;26:1094-99.

14. Global Guideline for Type 2 Diabetes: recommendations for standard, comprehensive, and minimal care. Diabet Med. 2006

15. Gottschall CBA, Álvares-da-Silva MR, Camargo ACR, Burtett RM, Silveira TR. Avaliação nutricional de pacientes com cirrose pelo vírus da hepatite $\mathrm{C}$ : a aplicação da calorimetria indireta. Arq. Gastroenterol. 2004;41:220-4.

16. Gottschall CBA, et al. Contribución de la dinamometría y la evaluación global del Royal Free Hospital en la evaluación nutricional de la enfermedad hepática crónica. Rev Chil Nutr. 2012;39:152-8.

17. Hollowell JG, Staehling NW, Flanders WD, Hannon WH, Gunter EW, Spencer CA, et al. Serum TSH, T(4), and thyroid antibodies in the United States population (1988 to 1994): National Health and Nutrition Examination Survey (NHANES III). J Clin Endocrinol Metab. 2002;87:489-99.

18. Ismail F, Khan R, Kamani L, Wadalawala A, Shah H, Hamid S, Jafri W. Nutritional status in patients with hepatitis C. J Coll Phys S Pakistan. 2013;22:139-142.

19. Jeejeebhoy KN, Detsky AS, Baker JP. Assessment of nutritional status. JPEN J Parenter Enteral Nutr. 1990;14:193-6.
20. Kappel CR, Kretzmann NA, Alvares-da-Silva MR. Expression in Hepatic Tissue and Leukocytes in Chronic Hepatitis C Virus Infected Patients: A Comparative Study. Int J Hepatol. 2012;2012:698905.

21. Lameu E, Gerude MF. Musculo Adutor do Polegar. In Clinica Nutricional. Ed. Revinter, Rio de Janeiro. 2005;189-96.

22. Larrey D, Couzigou P, Denis J. Chronic hepatitis C: management of side effects of treatment. Gastroenterol Clin Biol. 2007;31:20-28.

23. Liagnpunsakul S, Chalasani N. What do we recommend our patients with NAFLD about alcohol consumption? Am J Gastroenterol 2012 (In press).

24. Loguercio C, Federico A, Masarone M, Torella R, Blanco CDV, Persico M. The impact of diet on liver fibrosis and on response to interferon therapy in patients whit HCV-related chronic hepatitis. Am J Gastroenterol, 2008;103, 3159-3166.

25. Matos LC, Tavares MM, Amaral TF. Handgrip strength as a hospital admission nutritional risk screening method. Eur J Clin Nutr. 2007;61:1128-35.

26. McCullough AJ. Malnutrition and liver disease. Liver Transpl. 2000;6:85-96.

27. Michalczuk MT, Kappel CR, Birkhan O, Bragança AN, Álvares-da-Silva MR HOMA-AD in Assessing Insulin Resistance in Lean Noncirrhotic HCV Outpatients. Int J Hepatol. 2012;2012:576584.

28. Moctezuma-Velázquez C, et al. Nutritional assessment and treatment of patients with liver cirrhosis. Nutrition. 2013;29:1279-85.

29. Nahás EAP, Pontes A, Nahás J, De Lucca LA. Relação entre obesidade, menopausa e terapia de reposição hormonal. Reprod. Clim. 1988;13:28-31.

30. Nunes FF, et al. Avaliação nutricional do paciente cirrótico: comparação entre diversos métodos. Sci Med. 2012;22:12-17.

31. Oliveira-Filho AD, Costa FA, Neves SJF, Junior DPL, Morisky DE. Pseudoresistant hypertension due to poor medication adherence. Int J Cardiol. 2013;172:309-10.

32. Padilha PC, Rocha HF, Alves N, Peres WAF. Prevalência de doença hepática nãoalcoólica em crianças e adolescentes obesos: uma revisão sistemática. Rev. Paul. Pediatr. 2010;28:143-54.

33. Pretta S, Marchesini G, Caracausi L, Maracausi L, Macaluso FS, Cammà C, et al Industrial, not fruit fructose intake is associated with the severity of liver fibrosis in genotype 1 chronic hepatites C patients. J Hepatol. 2013;59:1169-76.

34. Rhee SY, Park SY, Hwang JK, Son J II, Chin SO, Kim YS, et al. Metabolic syndrome as an indicator of high cardiovascular risk in patients with diabetes: Analyses based on Korea National Health and Nutrition Examination Survey (KNHANES) 2008 Rhee et al. Diabetol Metab Syndr. 2014;6:98.

35. Ritter L, Gazzola J. Avaliação nutricional no paciente cirrótico: uma abordagem objetiva, subjetiva ou multicompartimental? Arq. Gastroenterol. 2006;43:66-70.

36. Schlüssel MM, Anjos LA, Kac G. A dinamometria manual e seu uso na avaliação nutricional. Rev. Nutr. 2008;21:223-35.

37. Siu PM, Yuen QS. Supplementary use of $\mathrm{HbA} 1 \mathrm{c}$ as hyperglycemic criterion to detect metabolic syndrome. Diabetol Metab Syndr. 2014;6:119.

38. Soler GLN, Silva AWSM, Silva VCG, Teixeira RJ. Doença Hepática Gordurosa NãoAlcoólica: associação com síndrome metabólica e fatores de risco cardiovascular. Rev SOCERJ. 2008;21:94-100.

39. White DL, Richardson PA, Al-Saadi M, Fitzgerald SJ, Green L, Amaratunge C, et al. Dietary history and physical activity and risk of advanced liver disease in veterans with chronic hepatitis C infection. Dig Dis Sci 2011;56:1835-47.

40. WHO (World Health Organization). Physical status: the use and interpretation of anthropometry. Geneva: Word Health Organization; 1995.

41. WHO (World Health Organization), 2005. Preventing Chronic Diseases: a vital investment: WHO Global report.

42. Wolf AM, Busch B, Kuhlmann HW, Beisiegel U. Histological changes in the liver of morbidly obese patients: correlation with metabolic parameters. Obes Surg. Oxford. 2005; 15:228-37.

43. Wong GLH. Prediction of fibrosis progression in chronic viral hepatites. Clin Mol Hepatol. 2014;20:228-36. 